\title{
Development and Psychometric Analysis of the Brief Inventory of Academic Procrastination
}

\author{
Gabriela Ballardin Geara ${ }^{\mathbf{1}}$ \\ Orcid.org/0000-0002-4966-6183 \\ Cristina Aparecida Medeiros Nunes", \\ Orcid.org/0000-0001-5223-7462 \\ Nelson Hauck-Filho ${ }^{2}$ \\ Orcid.org/0000-0003-0121-7079 \\ Marco Antônio Pereira Teixeira ${ }^{1}$ \\ Orcid.org/0000-0001-7981-9788 \\ ${ }^{1}$ Universidade Federal do Rio Grande do Sul, Porto Alegre, RS, Brasil \\ ${ }^{2}$ Universidade São Francisco, Itatiba, SP, Brasil
}

\begin{abstract}
Academic procrastination is characterized by the non-strategic postponement of commitments, implying a delay in starting or completing actions or decisions related to academic activities. This article describes the construction and psychometric analysis of a new self-report tool for the assessment of a broad spectrum of latent academic procrastination. Participants were 172 students from different undergraduate courses of a university in São Paulo (mean age $=23.66$; standard deviation $=6.61 ; 68 \%$ women). Factor analyses conducted on an initial 60-item pool yielded a unidimensional 20-item set, with items loading from moderate to high in a general factor of academic procrastination. Reliability found for the scale was .91 according to the alpha coefficient, and .93 according to omega, with a wide latent coverage, as suggested by the test information curve. The resulting instrument is available for research purposes in Brazil, and can be included in questionnaires of large-scale education assessments.
\end{abstract}

Keywords: Academic experiences, students, studying.

\section{Construção e Análise Psicométrica de um Inventário Breve de Procrastinação Acadêmica}

\section{Resumo}

Procrastinação acadêmica caracteriza-se pelo adiamento não estratégico de compromissos, o que implica protelar o início ou a conclusão de ações ou decisões relacionadas às atividades acadêmicas. $\mathrm{O}$ estudo descreve a construção de uma nova ferramenta de autorrelato com a finalidade de avaliar um amplo espectro latente de procrastinação acadêmica. Os participantes foram 172 estudantes universitários de

* Mailing address: Universidade São Francisco, Câmpus de Itatiba, Alexandre Rodrigues Barbosa, 45, Centro, Itatiba, SP - Brazil 13251900. Phone: (11) 4534-8046. E-mail: gearagabi@gmail.com, cristina_medeiros@, hotmail.com, hauck.nf@gmail.com and mapteixeira.psi@gmail.com 
diversos cursos de graduação de uma universidade do interior de São Paulo (média de idade = 23,66; desvio-padrão $=6,61 ; 68 \%$ mulheres). Análises fatoriais exploratórias permitiram selecionar 20 itens (de 60 iniciais) criados com base nas definições do construto presentes na literatura, que apresentaram cargas de magnitude moderada a alta em um fator geral de procrastinação. A fidedignidade encontrada para a escala foi de 0,91 pelo coeficiente alpha e 0,93 pelo coeficiente ômega, havendo uma ampla cobertura latente, como sugerido a partir da curva de informação do teste. $\mathrm{O}$ instrumento é recomendado para pesquisas no Brasil, podendo ser incluído em questionários contextuais em estudos de avaliação educacional em larga escala.

Palavras-chave: Vivências acadêmicas, estudantes, estudo.

\section{Desarollo y Análisis Psicométrico del Inventario Breve de la Procrastinación Académica}

\section{Resumen}

La procrastinación académica se caracteriza por el aplazamiento no estratégico de compromisos, lo que implica retrasar el inicio o la conclusión de acciones o decisiones relacionadas con las actividades académicas. Esto estudio describe la construcción de una nueva herramienta de autorrelación con la finalidad de evaluar un amplio espectro latente de procrastinación académica. Los participantes fueron 172 estudiantes universitarios de diversos cursos de graduación de una universidad del interior de São Paulo (media de edad $=23.66$, desviación estándar $=6.61,68 \%$ mujeres). Los análisis factoriales exploratorios permitieron seleccionar 20 ítems (de 60 iniciales) creados con base en las definiciones del constructo presentes en la literatura, que presentaron cargas de magnitud moderada a alta en un factor general de procrastinación. La confiabilidad encontrada para la escala fue de 0.91 por el coeficiente alfa, y 0.93 por el coeficiente omega, habiendo una amplia cobertura latente, como sugerido a partir de la curva de información de la prueba. El instrumento es recomendado para investigaciones en Brasil, pudiendo ser incluido en cuestionarios contextuales en estudios de evaluación educativa a gran escala.

Palabras clave: Vivencias académicas, estudiantes, estudio.

The word "procrastination" comes from the Latin expression "pro crastinus," in which "pro" corresponds to "in favor of" and "crastinus" means "tomorrow" (Burka \& Yuen, 1991). Therefore, the etymology of the word refers to the process of leaving something to be done in the future. Procrastination can be understood as a functional delay or as a way of avoiding haste and hurry (Chu \& Choi, 2005), and its negative connotation was established in the mid-eighteenth century, after the Industrial Revolution. Since then, procrastination has been associated with laziness, indolence, lack of ambition, and indifference (Ferrari, Johnson, \& McCown, 1995). In the academic context, procrastination can impact on performance (Kim \& Seo, 2015), becoming a possible variable of interest in large-scale educational assessments.
This article describes the development of a new free-use tool designed to capture the core features of academic procrastination in students.

The concept of procrastination cannot be confused with idleness, laziness, or delaying. Procrastination is the non-strategic postponement of actions (Schouwenburg, 2004). In procrastination, usually, a task is replaced by an activity that is more pleasurable but less important (Schouwenburg, 2004). Commonly, this substitution does not occur in idleness and laziness. In laziness, the core element is slowness and an aversion to the performance of tasks that require some form of physical and/or mental effort, while in idleness no task is performed.

Procrastination has other particularities. Three aspects of the intended task are important in the procrastination process: (a) a manifest 
action (a behavior) or a covert action (a decision) is delayed; (b) the beginning or the end of this action is desired; and (c) the action is necessary or has personal importance (Klingsieck, 2013). It is worth mentioning that the typical delay of procrastination, although unnecessary and irrational, occurs voluntarily (Klingsieck, 2013), even when potential negative consequences are involved in the situation (Steel, 2007). However, a person who procrastinates does not necessarily experiences satisfaction by delaying; conversely, procrastination tends to be accompanied by subjective discomfort (Solomon \& Rothblum, 1984), and it represents a dysfunctional way of coping with life obligations (Klingsieck, 2013).

The focus of the present study was on academic procrastination. In this context, procrastination is defined by the non-strategic postponement of commitments (Sampaio \& Bariani, 2011), delaying the beginning or the conclusion of actions or decision processes related to studying (Schouwenburg, 1995). It is estimated that, worldwide, academic procrastination is a phenomenon that occurs with approximately $70 \%$ of university students (Ferrari, O'Callaghan \& Newbegin, 2005). In addition, about half of university students procrastinate consistently and problematically (Day, Mensink, \& O'Sullivan, 2000; Solomon \& Rothblum, 1984).

Academic procrastination can be prejudicial to students. Since university life is characterized by a set of academic tasks to be accomplished within certain time frames, procrastinatory behavior can become salient when it occurs (Ferrari et al., 2005). Academic assignments are often not performed before the expected deadline or are left to be done at the last minute (Schouwenburg, 1995). As previously mentioned, this pattern of behavior may lead to a drop in students' academic performance, regardless of their level of cognitive functioning (Kim \& Seo, 2015). Postponement of activities such as daily studying or studying for tests and exams are especially connected to poor academic performance (Beswick, Rothblum, \& Mann, 1988; Burka \& Yuen, 1991; Sampaio \& Bariani, 2011; Solomon \& Rothblum, 1984).
Procrastination is a theme that has not been deeply investigated in Brazil. In one of the few epidemiological studies conducted so far, Sampaio and Bariani (2011) explored and described the most procrastinated tasks and the associated unpleasant feelings among university students. In this study, $82 \%$ of the students reported postponing their assignments, and $49 \%$ reported procrastinating at least once a week. The main reasons associated with procrastination were "lack of time" (34\%) and "dissatisfaction in performing the activity" (25\%), while some reported "no criterion" for this postponement (21\%). Students who procrastinated reported feeling anxiety $(19.6 \%)$, worry $(18.5 \%)$ and selfdepreciation (17.3\%; Sampaio \& Bariani, 2011). In a more recent study with a sample of Brazilian students, procrastination of academic tasks was reported by $82.6 \%$ of the participants (Geara, Hauck-Filho, \& Teixeira, 2017). The most frequently reported reasons for procrastinating academic tasks were laziness, fatigue and lack of time to perform the task (Geara et al., 2017).

A well-established approach to the assessment of procrastination is the selfreport. Several self-report inventories have been developed to capture different aspects of academic procrastination (Ferrari et al., 1995), among them: the Tuckman Procrastination Scale (TPS; Tuckman, 1991), the Procrastination Checklist Tasks (PCS; Schouwenburg, 1995), the Academic Procrastination State Inventory Tasks (APSI; Schouwenburg, 1995) and the Study Problems Questionnaire (SPQ; Schouwenburg, 1995). Despite being one of the first instruments published, the Procrastination Assessment Scale (PASS; Solomon \& Rothblum, 1984) still continues to be used in some investigations in the area.

Although adapting these popular procrastination inventories to Brazil is advantageous in that this could allow cross-cultural comparisons, some drawbacks should also be mentioned. One aspect to be considered is that the majority of the instruments were developed over two decades ago, in a time that does not reflect the current academic scenario, in which procrastination often involves the use of 
online social networks, smartphones and other electronic devices. Therefore, items from these instruments do not necessarily capture academic procrastination as it is experienced by the current generation of students. Another issue is that it cannot be assumed that academic procrastination is expressed in Brazil in the same way as in the other countries where these inventories were developed. Therefore, the construction of a selfreport instrument that is brief and at the same time informative regarding the core aspects of procrastination as manifested by students in this country would be justified.

Available instruments developed in Brazil have some specificities that should be mentioned. The Active Procrastination Scale (Gouveia, Pessoa, Coutinho, Barros, \& Fonseca, 2014) assesses broad characteristics of this behavior (ability to meet deadlines, intentional decision, preference for pressure and satisfaction with results), however, does not focus on a specific context, such as the academic context. Other measures are directed more toward academic procrastination, however, with a rather narrow content coverage. The Academic Procrastination Scale - Reasons (Geara et al., 2017) only asks participants about the reasons they procrastinate academic tasks. The Academic Procrastination Questionnaire - Negative Consequences (Geara $\&$ Teixeira, 2017) addresses the perception of the negatives effects of academic procrastination in several areas of life. Finally, the Academic Procrastination Scale (Sampaio, 2011) evaluates academic procrastination, however, contains items restricted to the tasks of daily studying and studying for exams.

Although all these instruments have excellent psychometric properties, they do not offer a more detailed assessment of the behaviors, beliefs and emotional states involved in current academic procrastination. None of these instruments were elaborated with the explicit purpose of contemplating different levels of the latent spectrum of procrastination - for example, none of them have a focus on more severe levels of academic procrastination. Items covering dysfunctional procrastination are desirable because they might be better suited to predicting academic impairment. Furthermore, as far as is known, no previous instruments have been developed with an explicit concern with minimizing response biases, such as acquiescence - the tendency to agree with items regardless of their content (Paulhus, 1991). Therefore, a refinement in the assessment of academic procrastination could be achieved with the development of an inventory that, in addition to being brief and informative, would be able to control for acquiescent responding.

In brief, some gaps in the available instruments inspired the development of a new inventory of academic procrastination. More specifically, the new instrument should: (a) be specific to the national academic context, (b) be comprehensive in providing a broad coverage of the latent aspects of procrastination, and (c) allow the control of response styles such as acquiescence. Such a scale would allow a reliable assessment of varying levels of academic procrastination, ranging from behaviors with little impact to those most detrimental to student performance. Therefore, the present article reports the development and psychometric analysis of a Brazilian instrument capable of capturing more extreme or severe levels of procrastination, the Brief Inventory of Academic Procrastination (BIAP). The scale was designed to reconcile the goal of high reliability with a small number of items, so that it can also be used in large-scale educational assessments in Brazil. It is expected that the BIAP will provide a more refined procrastination assessment with greater predictive potential for future studies in the area.

\section{Method}

\section{Participants}

Participants were 172 university students from a university in São Paulo state (mean age $=23.7$, standard deviation $=6.61,68 \%$ women). With respect to ethnicity, $76.5 \%$ declared themselves white, $17.5 \%$ brown, $4.0 \%$ black and $2.0 \%$ Asian. The majority of the participants $(66.5 \%)$ reported an income that varied from 1 to 5 minimum wages. Regarding relationship status, $53.46 \%$ were single, $32.67 \%$ 
were dating, $12.38 \%$ were married, and $1.49 \%$ were separated. At the time of data collection, the participants were enrolled in the following undergraduate courses: Psychology $(n=72)$, Technology in Logistics $(n=50)$, Physiotherapy $(n=38)$, Technology in Management Processes $(n=14)$, Nursing $(n=9)$, and others (Electrical Engineering, Information System or Civil Engineering, $n=5$ ).

\section{Instrument}

The Brief Inventory of Academic Procrastination was designed to assess different levels and aspects of academic procrastination. To do this, 60 preliminary items were devised by the authors of the present study, based on a consultation of international instruments about procrastination and on the seven aspects of procrastination proposed by Klingsieck (2013), as described in Table 1. A series of items covering each theoretical facet of procrastination was designed. As well as developing indicators related to mild to moderate levels of procrastination, statements that could reflect more severe and harmful manifestations of procrastination among students (e.g., often failing to accomplish tasks) were also created. To be comprehensible to students from many educational settings (schools and universities, either public or private), special care was given to the wording of the items, avoiding complex sentences or words with a low frequency of use in Brazilian Portuguese. Furthermore, redundancy of content across items was avoided when feasible. The theoretical relevance of each item was evaluated through multiple discussions and refinements by the authors of the present study. Respondents rated items on a five-point Likert scale, in which 1 corresponds to "The phrase is totally false in relation to me (does not correspond in any way to how I feel, think or act)" and 5 corresponds to "The phrase is totally true in relation to me (corresponds perfectly to the way I feel, think or act)".

The control of acquiescence designed for this instrument is based on the inclusion of positive and negative items (Cloud \& Vaughan,
1970). This means that some items were designed in the same direction as procrastination, while the scores of others are negatively related. Agreement with item statements will tend to occur more easily when all items are written in the same direction as the trait ("I postpone my academic appointments even being aware of the possible negative consequences"). By contrast, also including reverse-keyed items ("I always schedule myself to study in advance in pursuit of better results") will require more attention from the respondents, thus stimulating a more varied and cautious use of the response scale (Paulhus, 1991). Another advantage when there are positive and negative items lies in the possibility of implementing some procedures for correcting acquiescence (Hofstee, Berge, \& Hendriks, 1998), as described and performed later in the text. For this reason, it was established that the final scale should comprise a balanced selection of items, with half the items covering the positive descriptive pole of procrastination and half the negative pole (Cloud \& Vaughan, 1970).

\section{Procedure}

The project was previously approved by the Institutional Review Board from the University of São Francisco - São Paulo CAAE 34983314.1.0000.5514. All participants signed a consent form. After approval from the director of the campus and the coordinators of the courses, data collection in the classrooms was scheduled with the professors. The average time for a collective application was 20 minutes.

\section{Data Analysis}

The feasibility of subjecting the data to a factor analysis was assessed using the KeiserMeyer-Olkin (KMO) index, and the decision on the number of factors to retain was guided by the Hull method. Parameters from the exploratory factor model were estimated using the item polychoric correlation matrix and the Weighted Least Squares- Mean and Varianceadjusted (WLSMV) estimator. The WLSMV estimator, which does not assume a normal distribution of indicators, has been recently 
Table 1

Procrastination Aspects (Klingsieck, 2013) Considered in the Design of the Items

Aspects Description N

Delaying

an action

Intension to

perform

an action

Importance

of the action

Voluntary

delay

Unnecessary

delay

Awareness of possible negative consequences (risk)

Presence of negative consequences
An action/behavior or an action/thought is delayed. Organizing yourself mentally and planning something are examples of covert actions that we often procrastinate. So, procrastination is not always a phenomenon observable by outsiders. The focus here is that something was left for later. It is purely the question of putting off, doing later or doing after something that could be done now.

The procrastinator wants to start or finish the task. He plans this in the sense that he intends to accomplish the task, but that does not mean that he has adequate or detailed planning for the execution of the task. It is worth remembering that procrastination can happen before the task starts, during the task or before finishing it. It is important to show that the person intends/planned/thinks that this task should be completed or at least initiated.

The procrastinator realizes that the task needs to be performed or gives personal importance to the task. This does not entail willingness or motivation to start or finish the task, but the procrastinator perceives this task as something that needs to be accomplished. The person expects to get the action/task done. This aspect emphasizes that procrastinated tasks are important in some way: either they are necessary because of the context or they are important for the person because of a value/importance assigned to the task.

The postponement occurs without external pressure that justifies this postponement. The procrastinator is not being forced to postpone the action because something out of his/her control happened. The task is no longer accomplished, in such a way that it can be said that postponement is voluntary, since it is something that starts from the subject - it is a decision taken freely'.

The postponement occurs without a rationality/logic or an understandable/ justifiable need. The procrastinator does not reflect much on his real motives for procrastinating, acting this way without realizing exactly what is happening. The person understands that delaying is unnecessary considering the circumstances or context, but ends up procrastinating precisely because this understanding does not affect his procrastinatory behavior which is based on an irrational process of postponing tasks.

Delaying the task accomplishment occurs even when the procrastinator is aware of the possible negative consequences of doing that. The person realizes that procrastinating the task represents a risk of having some loss or disadvantage, however, being aware of this risk does not "prevent" him or her from actually procrastinating. Here the focus is to assess the perception of the possible negative consequences of procrastination.

Postponement of the task is accompanied by some form of subjective discomfort (guilt, regret, stress, anxiety, etc.) or other negative consequences (low grades, failure in disciplines, etc.). These negative consequences that the subject perceived (previous facet) or even other unexpected consequences that could happen are in fact something bad in the person's life. This discomfort resulting from procrastination is an essential part of the definition of procrastination. There is no procrastination in the absence of negative consequences or subjective discomfort (in this case it would be a strategic postponement). 
reported as one of the most recommended approaches for the analysis of Likert-type data (see Asún, Rdz-Navarro, \& Alvarado, 2015). Reliability of the final item pool was measured via alpha and omega coefficients, and the test information curve. Whereas the first approach addresses the overall internal consistency of the selected indicators, the latter is more precise, as it describes the expected reliability of scores for each latent trait level. The analyses were performed using the R, Factor (Lorenzo-Seva \& Ferrando, 2013), and Mplus 8.0 (Muthén \& Muthén, 2017) programs.

In addition, a Multiple-Indicator, MultipleCause model (MIMIC) was fit to the data to estimate item factor loadings while controlling for acquiescent responding. Figure 1 presents this MIMIC model. The main idea was to include an index of acquiescent responding as an item response covariate, so that the direct effect of the latent factor of procrastination over items (i.e., the factor loadings) would be estimated after accounting for acquiescence. Multidimensional modeling of response styles can help separate trait variance from other systematic variance components that are irrelevant to measuring the trait of interest (Wetzel \& Carstensen, 2015).
The method employed for deriving the acquiescence index was quite simple. It consisted of the mean score obtained by each individual on a chosen set of semantically opposed item pairs from the item pool (Hofstee et al., 1998). The rationale behind this procedure is that, given a 5-point Likert scale, if items are perfectly antonymous in content and individuals rate them consistently, then the expected mean score would be 3 . For instance, if an individual gives 5 to the item "I never procrastinate in my academic tasks," then one should expect a response of 1 from the same individual to "I always procrastinate in my academic tasks". Following the same reasoning, if someone rates 2 for the first item, a response of 4 is expected for the latter, and so forth. Evidently, the mean for consistent responses will always converge to 3. However, some individuals will not respond consistently, so that their mean scores in the set of item pairs will tend to be more or less than 3 , indicating a tendency to agree or disagree (respectively) with items regardless of their descriptive content. In the present study, the item pairs used to compose the acquiescence index were: items 9 and 19,2 and 18, 10 and 12, and 7 and 13 (see Table 2), which yielded a mean very close to $3($ mean $=2.9, S D=0.47)$.

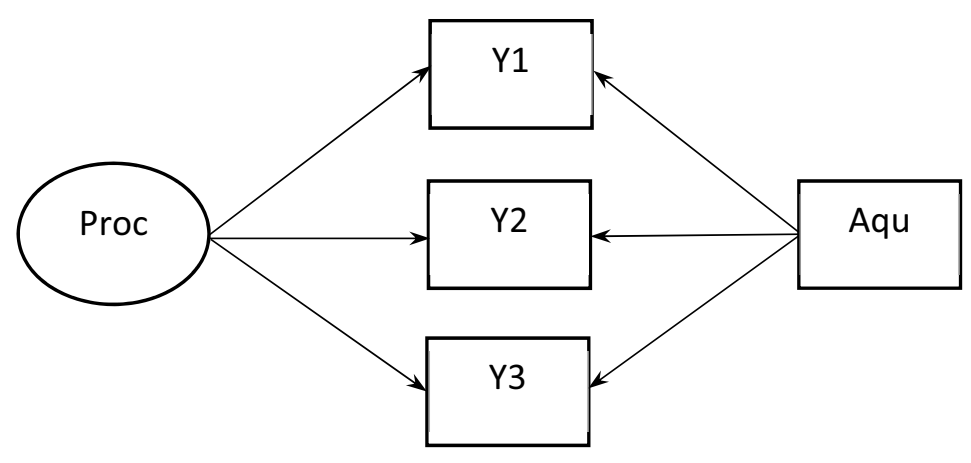

Figure 1. MIMIC Model to Control for Acquiescence.

\section{Results}

The initial 60-item pool was deemed adequate for a factor analysis, as indicated by the KMO index (.89). The Hull method suggested that a one-factor solution would represent the best fit to the data, therefore, it was decided to further inspect the interpretability of this model. As the intention was to retain a small set of highly discriminative items, only those with a communality of at least .20 were selected. In cases where items were too similar in content, the 
one with the highest factor loading was selected. Another concern was maintaining a balanced number of positively and negatively keyed items. This resulted in a final set of 20 items (10 positive, 10 negative) presenting factor loadings ranging from .51 to .83 in a general factor of academic procrastination. The size of the item factor loadings produced indicates a moderate to high capacity to provide information on the latent factor. Parameter estimates are described in Table 2 (items in Brazilian Portuguese).

Table 2

Item Factor Loadings for the one-factor and the MIMIC Model

\begin{tabular}{|c|c|c|c|c|}
\hline & & & Ml & $\mathrm{IC}$ \\
\hline & & Factor & Factor & $\mathrm{Aqu}$ \\
\hline 1 & $\begin{array}{l}\text { Escolho deixar minhas tarefas para depois quando tenho algo mais interessante } \\
\text { para fazer. }\end{array}$ & 0.65 & 0.66 & 0.25 \\
\hline 2 & $\begin{array}{l}\text { Tento me concentrar para realizar alguma atividade necessária, mas acabo } \\
\text { desviando meu pensamento para coisas de menor importância. }\end{array}$ & 0.63 & 0.63 & 0.35 \\
\hline 3 & Adio, por conta própria, a realização das minhas tarefas da universidade. & 0.69 & 0.68 & 0.29 \\
\hline 4 & $\begin{array}{l}\text { Mesmo que eu possa me arrepender, acabo atrasando meus trabalhos da } \\
\text { faculdade. }\end{array}$ & 0.83 & 0.83 & 0.26 \\
\hline 5 & $\begin{array}{l}\text { Mesmo que eu me organize antes, muitas vezes, não consigo terminar meus } \\
\text { deveres acadêmicos. }\end{array}$ & 0.56 & 0.57 & 0.25 \\
\hline 6 & $\begin{array}{l}\text { Adio meus compromissos acadêmicos mesmo estando ciente das possíveis } \\
\text { consequências negativas. }\end{array}$ & 0.81 & 0.81 & 0.21 \\
\hline 7 & $\begin{array}{l}\text { Eu adio tomar decisões sobre minhas atividades acadêmicas até ser obrigado a } \\
\text { fazer isso. }\end{array}$ & 0.63 & 0.64 & 0.23 \\
\hline 8 & $\begin{array}{l}\text { Mesmo que eu tenha a intenção de terminar uma tarefa, acabo deixando para } \\
\text { depois. }\end{array}$ & 0.64 & 0.64 & 0.29 \\
\hline 9 & $\begin{array}{l}\text { Quando tenho muitas tarefas a terminar, acabo não dando conta de nenhuma } \\
\text { delas. }\end{array}$ & 0.54 & 0.55 & 0.36 \\
\hline 10 & $\begin{array}{l}\text { Costumo estar com meus estudos atrasados em disciplinas que não despertam } \\
\text { o meu interesse. }\end{array}$ & 0.51 & 0.52 & 0.34 \\
\hline 11 & $\begin{array}{l}\text { Eu me organizo para ter tempo suficiente para fazer até as atividades mais } \\
\text { chatas. }\end{array}$ & -0.68 & -0.65 & 0.33 \\
\hline 12 & Costumo terminar meus trabalhos antes da data prevista para a entrega. & -0.56 & -0.52 & 0.49 \\
\hline 13 & $\begin{array}{l}\text { Sempre me programo para estudar com antecedência na busca por ter melhores } \\
\text { resultados. }\end{array}$ & -0.70 & -0.67 & 0.34 \\
\hline 14 & $\begin{array}{l}\text { Busco sempre terminar os trabalhos acadêmicos que são fundamentais para o } \\
\text { meu futuro. }\end{array}$ & -0.57 & -0.57 & 0.28 \\
\hline 15 & Sempre cumpro meu planejamento de estudos antes de uma prova importante. & -0.56 & -0.51 & 0.41 \\
\hline 16 & $\begin{array}{l}\text { Preparo-me com antecedência se sei que terei consequências ruins caso não me } \\
\text { empenhe na tarefa. }\end{array}$ & -0.70 & -0.66 & 0.32 \\
\hline 17 & $\begin{array}{l}\text { Quando estou envolvido em um projeto em grupo, sempre preparo minha parte } \\
\text { com antecedência. }\end{array}$ & -0.67 & -0.64 & 0.39 \\
\hline 18 & Eu insisto/persevero até ver minha meta atingida. & -0.51 & -0.48 & 0.39 \\
\hline 19 & Mantenho meus trabalhos em dia mesmo estando com minha agenda lotada. & -0.69 & -0.69 & 0.25 \\
\hline 20 & Eu faço todas as tarefas que eu considero que deveriam ser feitas. & -0.69 & -0.68 & 0.20 \\
\hline
\end{tabular}


It should be mentioned that the one-factor model yielded a poor fit to the data, $\chi^{2}(170)=$ $618.65, \mathrm{RMSEA}=.124, \mathrm{CFI}=.848, \mathrm{TLI}=.830$, demonstrating that simplicity and parsimony came at the expense of neglecting other latent causes of item responses. One hypothesis that can be advanced here is that a proportion of the systematic variance shared by the indicators would be due to response styles, especially acquiescence. To investigate this possibility, the MIMIC model was tested, including an acquiescence index as a covariate of item responses. The approximate fit of the model to the data was quite reasonable, $\chi^{2}(170)=364.58$, RMSEA $=.082$, CFI $=.935$, TLI $=.920$.

Furthermore, as presented Table 2, the estimated factor loadings remained close to those of the simple one-factor model, with a decrease in magnitude for items receiving a larger direct path from the acquiescence indicator (e.g., 12 and 15). A further inspection of the modification indices from the MIMIC analysis indicated that items 12 and 15 had a moderate residual correlation of $r=.38$, possibly because they both refer to planning and executing tasks before their deadline expires. When modeling this residual correlation, the fit of the MIMIC model improved, $\chi^{2}(169)=302.61$, RMSEA $=.068, \mathrm{CFI}=.955, \mathrm{TLI}=.945$. These results confirm the unidimensionality of the selected items, suggesting that acquiescence was the primary reason for the poor fit of the simpler unidimensional model. Another interesting result was that all the standardized coefficients from the acquiescence to items variable were positive, confirming that this response style acted as the main effect that inflated item scores irrespective of their descriptive content (Paulhus, 1991).

Next, the internal consistency and the test information curve produced by the final 20item pool were analyzed. Internal consistency was high at .91 according to the alpha, and .93 according to the omega coefficient. This supports the capability of the instrument to provide a concise measure of academic procrastination with a minimal amount of error. Nevertheless, these internal consistency estimates do not precisely measure the levels in the latent continuum where the test achieves its reliability peak. Accordingly, these analyses were supplemented with a test information curve, which allows a more accurate analysis of test reliability across the latent trait and helps to identify whether items indeed cover a broad range of the academic procrastination continuum. The results are presented in Figure 2.

The graph confirms that, as well as being highly reliable, the test can be used for the assessment of a wide range of procrastination levels, including individuals that exhibit almost no procrastination behaviors (e.g., -2 standard deviations bellow the mean, on the graph) up to individuals with severe procrastination problems (e.g., 2 standard deviations above the mean, on the graph). The latent interval from -2 to 2 comprised $71.69 \%$ of the area under the information curve. The information peak occurred above the latent mean, therefore supporting the use of the instrument for identifying students with severe problems involving academic procrastination in intervention studies or large-scale assessments.

\section{Discussion}

The present article describes the procedures of development and psychometric analysis of the Brief Inventory of Academic Procrastination (BIAP), a brief 20-item self-report scale. The findings from the factor analysis indicate that positive and negative items prepared for the BIAP provide information about the same latent variable, a general factor of academic procrastination. This overall factor represents an individual tendency to postpone commitments, divert from academic tasks to less important activities, reduce study planning, and feel motivated to complete academic tasks only when there is a high level of urgency. Thus, high scores in this factor may characterize maladaptive functioning in the academic context. 


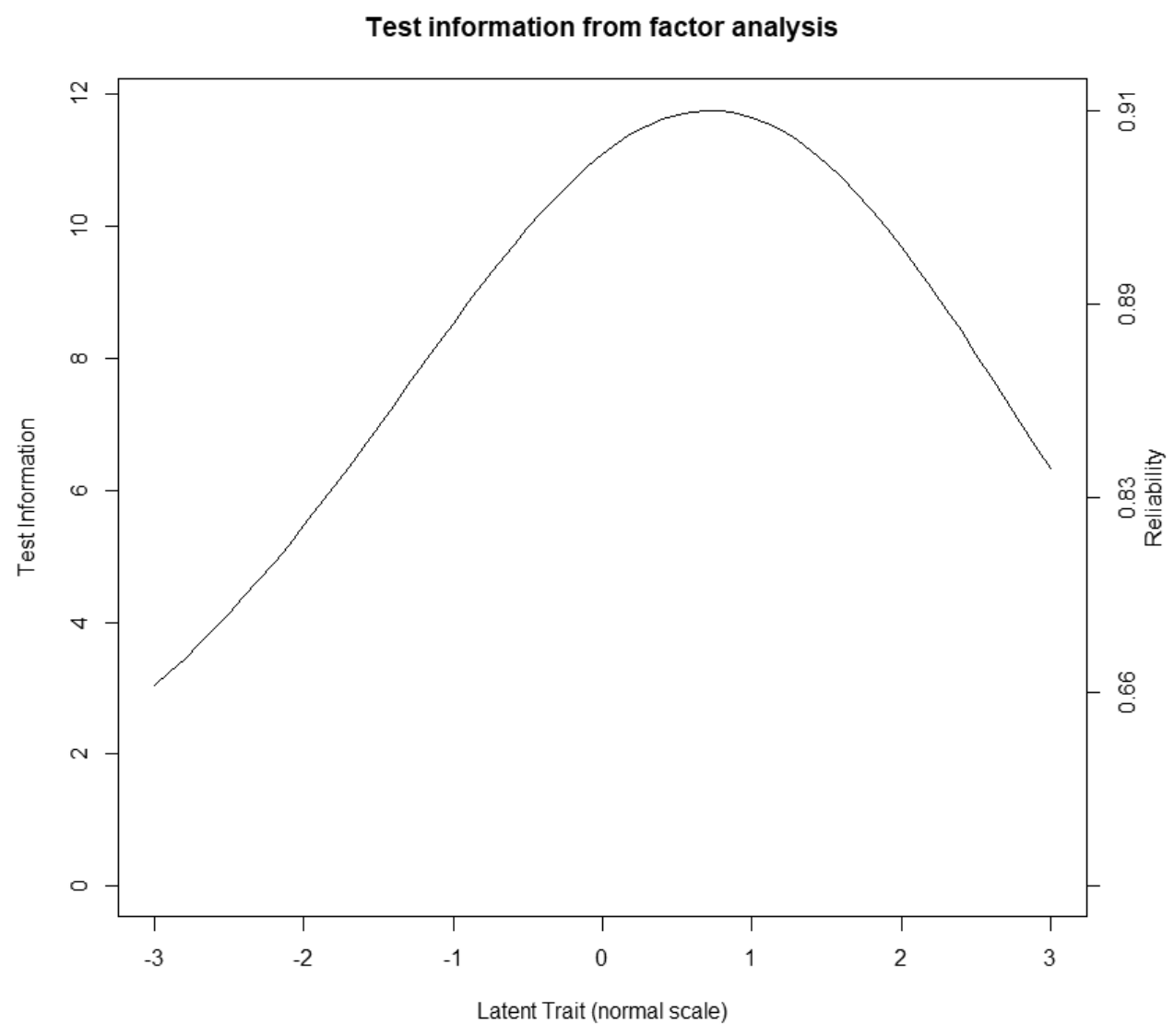

Figure 2. Test Information Curve.

Accordingly, the BIAP is indicated for use in studies with the purpose of relating academic procrastination to outcomes and variables typical of the academic context, such as performance, academic experiences, evasion rates, etc. Composed of only 20 items, the BIAP represents an excellent alternative to be included in contextual questionnaires in large-scale educational assessment studies in Brazil. The instrument is free to use, and no authorization is required for its use in research, only credit to the authors.

The unidimensionality of the instrument deserves further comment. Although no collateral measures of broad procrastination were included in the present study, it was hypothesize that the BIAP general factor would correlate positively (at least moderately) to these other instruments. This expectation is based on the property of procrastination as a trait that explains behaviors in various contexts (Steel, 2007). If this holds true, academic procrastination is a more generalized tendency of behavior, and not a special type of procrastination (Conceição, 2011). Individuals who procrastinate in their academic tasks, will likely also act in this way in other situations, since the negative reinforcement effect resulting from the avoidance or escape of the task can be generalized to different contingencies. The term "academic" simply refers to the context in which the procrastination is manifested.

Therefore, the purpose of this instrument is not to assess a latent variable that is nonexistent in available instruments, but to provide a more valid and reliable selection of indicators of the phenomenon in the current academic context (objective "a" of the study). Even though the BIAP was elaborated based on the seven aspects listed by Klingsieck (2013), the findings of the present study support the existence of a general procrastination tendency that might also manifest in other contexts.

The BIAP scale, despite being brief, produces highly reliable scores. Both the traditional 
alpha and omega coefficients achieved values above .90 , indicating high internal consistency and reduced measurement error. Furthermore, because the BIAP was constructed with the purpose of providing a wide coverage of the latent trait (objective "b" of the study), an analysis of the test information curve was also performed. The findings reveal, as expected, a large area under the test information curve. Particularly noteworthy is the fact that the instrument obtained a reliability estimate above .80 for scores ranging from two standard deviations below the mean to three standard deviations above. In addition, the curve found was slightly displaced to the right, which confirms that the scale obtains its peak of informative capacity in individuals with a level of procrastination above the population mean (that is, of the students in general). This suggests that BIAP can be used in follow-up procedures and longitudinal studies with clinical groups.

Another result that deserves attention was the control of acquiescence. The intention was to construct the BIAP in a way that it contained both positive and negative items, to prevent acquiescent responding and provide the means to control it (Hofstee et al., 1998; objective "c" of the study). Although a one-dimensional model was not fully capable of replicating the pattern of observed data, the inclusion of an acquiescence index as an item covariate improved the approximated fit. Whereas this finding suggests that acquiescence was present as a variance component of the item scores, including this covariate in the model caused only minimal changes in item factor loadings in the general factor of procrastination. In other words, common variance was mainly due to the procrastination factor, not to response styles. Therefore, replicating the MIMIC procedures here described will assist future researchers interested in controlling acquiescence when using the BIAP. Furthermore, in the context of a broader structural equation model, the MIMIC may more accurately reveal the relationship between the general factor of academic procrastination and other variables of interest to the researcher.
Although these preliminary results were favorable, further studies are still needed to establish the predictive capacity of the BIAP relative to other variables. As previously mentioned, one priority should be the investigation of convergent relationships with instruments that more broadly assess procrastination. Evidence also indicates that procrastination is negatively associated with the learning process and academic performance (Kim \& Seo, 2015). Therefore, investigating the relationship with academic outcomes would represent a crucial test for the predictive capacity of the BIAP. For example, this would make it possible to establish the extent to which high scores in the instrument indicate possible impairments in academic performance, helping to predict student performance before exams take place. In addition, studies should test whether the pattern of correlations of the BIAP to scores in the Big Five factors of personality replicate findings reported when using broader measures of procrastination. Procrastination tends to be negatively related to conscientiousness, which is characterized by disposition for self-discipline, persistence, regulation, order and control. Authors have also reported positive correlations to neuroticism, suggesting that the procrastinator tends to experience anger, sadness, anxiety, stress and frustration (Schouwenburg, 2004; Steel, 2007). Replicating these associations will strengthen the theoretical status of academic procrastination as a genuine personality disposition.

The present study has some limitations that should be mentioned. Firstly, as previously mentioned, this preliminary study did not include any measures of the predictive capacity of the scale developed here. Establishing the extent to which the scores can predict academic, clinical and other life outcomes should comprise the next step in the psychometric analysis of the BIAP. Secondly, the sample was relatively small $(n=$ 172), so that the factor structure produced and the stability of the estimated item parameters should also be investigated with a larger Brazilian sample. It should be emphasized that the non-random sample contained an unequal 
number of students from each academic area, as the focus of the present study was not to address mean comparisons across these groups. New studies should focus on a more balanced sample composition, especially considering that reliable group comparisons might be dependent on this matter. Thirdly, a possible incremental effect on the item responses due to demographic variables such as gender, ethnicity, or even region of origin of the participant was not investigated. In the technical literature, this incremental influence is called differential item functioning (DIF) and consists of an undesirable bias that may underestimate or even overestimate betweengroup mean differences (Millsap, 2011). Thus, it is still unknown whether the BIAP items present DIF (and if so, which ones), a topic yet to be explored.

Fourthly, although the effect of acquiescence was controlled, other equally important response styles, such as extreme responses, were not accounted for. New studies could include factors of extreme responses in the MIMIC, especially considering advances in the multidimensional assessment of response styles (Wetzel \& Carstensen, 2015). Finally, latent state-trait models (Steyer, Ferring, \& Schmitt, 1992) would allow a deeper understanding of the variance components that contribute to the instrument's scores. These models are capable of partialling out the true trait variance that is stable from the variance that is reliable but pertains to changing psychological features, thus resulting in more precise estimates of reliability of the scores in capturing a trait of academic procrastination.

\section{Final Considerations}

The present study presented the Brief Inventory of Academic Procrastination (BIAP) as an instrument for research purposes in Brazil. It can be used to promote student reflection on this topic through an individual or group analysis of the items. Its application is recommended in educational and academic performance services where it can be used as support material in various programs and clinical cases. Due to its brevity, the BIAP can also be included in questionnaires of large-scale educational assessments.

\section{Authors' Contributions}

Substantial contribution in the concept and design of the study: Gabriela Ballardin Geara.

Contribution to data collection: Cristina Aparecida Medeiros Nunes.

Contribution to data analysis and interpretation: Nelson Hauck Filho.

Contribution to manuscript preparation: Cristina Aparecida Medeiros Nunes, Gabriela Ballardin Geara, Marco Antônio Pereira Teixeira, Nelson Hauck Filho.

Contribution to critical revision, adding intelectual content: Cristina Aparecida Medeiros Nunes, Gabriela Ballardin Geara, Marco Antônio Pereira Teixeira, Nelson Hauck Filho.

\section{Conflicts of interest}

The authors declare that they have no conflict of interest related to the publication of this manuscript.

\section{References}

Asún, R. A., Rdz-Navarro, K., \& Alvarado, J. M. (2015). Developing multidimensional Likert scales using Item Factor Analysis: The case of four-point items. Sociological Methods \& Research, 45(1), 109-133. doi: $10.1177 / 0049124114566716$

Beswick, G., Rothblum, E. D., \& Mann, L. (1988). Psychological antecedents of student procrastination. Australian Psychologist, 23, 207-217. doi: 10.1080/00050068808255605

Burka, J., \& Yuen, L. (1991). Procrastinação. São Paulo, SP: Nobel.

Cloud, J., \& Vaughan, G. M. (1970). Using balanced scales to control acquiescence. Sociometry, 33(2), 193. doi: $10.2307 / 2786329$

Conceição, J. P. O. (2011). Personalidade e procrastinação em estudantes universitários (Master's thesis, Universidade Lusófona de Humanidades e Tecnologias, Lisboa, Portugal).

Chu, A. H. C., \& Choi, J. N. (2005). Rethinking procrastination: Positive effects of "active" 
procrastination behavior on attitudes and performance. The Journal of Social Psychology, 145, 245-264. doi: 10.3200/SOCP.145.3.245264

Day, V., Mensink, D., \& O’Sullivan, M. (2000). Patterns of academic procrastination. Journal of College Reading and Learning, 30, 120-134. doi: 10.1080/10790195.2000.10850090

Ferrari, J. R., Johnson, J. L., \& McCown, W. G. (1995). Procrastination and task avoidance: Theory, research, and treatment. New York: Plenum Press.

Ferrari, J, O’Callaghan, J., \& Newbegin, I. (2005). Prevalence of procrastination in the United States, United Kingdom, and Australia: Arousal and avoidance delays among adults. North American Journal of Psychology, 7(1), 1-6.

Geara, G. B., Hauck-Filho, N., \& Teixeira, M. A. P. (2017). Construção da escala de motivos da procrastinação acadêmica. Psico, 48(2), 140151. doi: 10.15448/1980-8623.2017.2.24635

Geara, G. B., \& Teixeira, M.A.P. (2017). Questionário de Procrastinação Acadêmica - Consequências negativas: Propriedades psicométricas e evidências de validade. Avaliação Psicológica, 16(1), 59-69. doi: 10.15689/ap.2017.1601.07

Gouveia, V. V., Pessoa, V. S., Coutinho, M. L., Barros, I. C. S., \& Fonseca, A. A. (2014). Escala de procrastinação ativa: Evidências de validade fatorial e consistência interna. Psico-USF, 19, 345-354. doi: 10.1590/141382712014019002008

Hofstee, W. K. B., Berge, J. M. F. T., \& Hendriks, A. A. J. (1998). How to score questionnaires. Personality and Individual Differences, 25(5), 897-909. https://doi.org/10.1016/S01918869(98)00086-5

Kim, K. R., \& Seo, E. H. (2015). The relationship between procrastination and academic performance: A meta-analysis. Personality and Individual Differences, 82, 26-33. doi: 10.1016/j. paid.2015.02.038

Klingsieck, K. B. (2013). Procrastination: When good things don't come to those who wait. European Psychologist, 18(1), 24-34. doi: 10.1027/10169040/a000138

Lorenzo-Seva, U., \& Ferrando, P. J. (2013). FACTOR 9.2: A comprehensive program for fitting exploratory and semiconfirmatory factor analysis and IRT models. Applied Psychological Measurement, 37(6), 497-498. doi: $10.1177 / 0146621613487794$

Millsap, R. E. (2011). Statistical approaches to measurement invariance. New York: Routledge, Taylor \& Francis Group.

Muthén, L. K., \& Muthén, B. O. (2017). Mplus user's guide (7rd Ed). Los Angeles, CA: Author.

Paulhus, D. L. (1991). Measurement and control of response styles. In J. P. Robinson, P. R. Shaver, \& L. S. Wrightsman (Eds.), Measures of personality and social psychological attitudes (pp. 17-59). San Diego, CA: Academic Press.

Sampaio, R. K. N. (2011). Procrastinação acadêmica e a autorregulação da aprendizagem em estudantes universitários (Master's thesis, Universidade Estadual de Campinas, SP, Brazil).

Sampaio, R. K. N., \& Bariani, I. C. D. (2011). Procrastinação Acadêmica: Um estudo exploratório. Estudos Interdisciplinares em Psicologia, 2(2), 242-262. doi: 10.5433/2236-6407.2011v2n2p242

Schouwenburg, H. (1995). Academic procrastination: Theoretical notions, measurement and research. In J. Ferrar, J. Johnson, \& W. McCown (Eds.), Procrastination and task avoidance: Theory, research and practice (pp. 71-95). New York: PlenumPress.

Schouwenburg, H. (2004). Trait procrastination in academic settings: An overview of students who engage in task delays. In H. Schouwenburg, C. Lay, T. Pylchyl, \& J. Ferrari (Eds.), Counseling the procrastinator in academic settings (pp. 3-18). Washington, DC: American Psychological Association.

Solomon, L., \& Rothblum, E. (1984). Academic procrastination: Frequency and cognitivebehavioral correlates. Journal of Counseling Psychology, 31(4), 503-509. doi: 10.1037/00220167.31.4.503

Steel, P. (2007). The nature of procrastination: A meta-analytic and theoretical review of quintessential self-regulatory failure. Psychological Bulletin, 133, 65-94. doi: 10.1037/0033-2909.133.1.65

Steyer, R., Ferring, D., \& Schmitt, M. J. (1992). States and traits in psychological assessment. European Journal of Psychological Assessment, 8(2), 79-98. 
Tuckman, B. W. (1991). The development and concurrent validity of the procrastination scale. Educational and Psychological Measurement, 51, 473-480. doi: 10.1177/0013164491512022

Wetzel, E., \& Carstensen, C. H. (2015). Multidimensional modeling of traits and response styles. European Journal of Psychological
Assessment, 1-13. doi: 10.1027/1015-5759/ a000291

Received: 04/04/2018

$1^{\text {st }}$ revision: $15 / 10 / 2018$

Accepted: 16/10/2018 distribution, and reproduction in any medium, provided you give appropriate credit to the original author(s) and the source, provide a link to the Creative Commons license, and indicate if changes were made. 